\title{
Cash Settled Commodity Option Contracts as an Alternative to Minimum Support Price: A Mechanism to Alleviate Farmer Distress
}

\author{
Sree Rama Murthy Y \\ Department of Economics and Finance, CEPS, Sultan Qaboos University, Muscat, Oman \\ murthy@squ.edu.om
}

\begin{abstract}
Cash settled commodity options is a possible alternative to create a mechanism so that minimum support prices work in reality and do not remain a paper exercise. This paper argues that the government should create a commodity options market for all minimum support price (MSP) commodities. Further option contracts should be cash settled. The government should participate by selling put options at or above the minimum support price, so that farmers can exercise the option if they find that market prices are below the minimum support price.
\end{abstract}

Keywords: Commodity options, farmers' distress, cash settled options, minimum support price mechanism.

\section{Introduction}

Volatility in prices of agriculture commodities in India has been a worrisome problem for crop producers, especially small farmers in India. The problem is of relevance for agro-food producers, not only in India, but in many countries across the world. Volatility in crop prices has led to farmers' distress in India and has become a matter of great concern for Indian policy makers. Agricultural commodity prices are cyclical. High prices in one year lead to higher production the following year which in turn may result in excess of supply over demand and consequently low, un-remunerative price. India has a "minimum support price" policy for the last several decades. The administrative support mechanism underlying the implementation of the MSP policy is supposed to ensure that the government agencies will buy farmers output at a minimum support price if the farmers choose to sell to the government. Minimum Support Price (MSP) is a form of market intervention by the Government of India to insure agricultural producers against any sharp fall in farm prices. Twenty two crops are covered under the MSP policy. The support price is fixed by Government of India in consultation with CACP (Commission for Agriculture Costs and Prices) to protect the producer - farmers against excessive fall in price during bumper production years (Planning Commission , 2006). Minimum support price mechanism does not work, except in a few major crops like rice and wheat. In case of other commodities there is no effective mechanism for buying the produce by government agencies at the minimum support price (Ahluwalia, 2019). The logistics and the infrastructure required to create an effective mechanism for the government to buy, store and distribute other MSP commodities is a herculean task. Establishing a cash-settled commodity option market could be a solution to the problem.

\section{Review of Literature}

Cash settled options allow trading of commodities, indexes and other instruments for which delivery is inconvenient or impossible (Cornell, 1997). For many commodities the spot markets are fragmented and derivative markets such as futures and option markets help in price discovery. Some exchanges such as Chicago Mercantile Exchange (CME) have moved futures and option contracts from physical delivery to cash settlements to attract more commercial interest and to reduce price volatility (Chan \& Lein, 2003). Cash settlement apart from augmenting price discovery also improves the hedging performance of the derivative contracts (Lein, Cash settlement provisions on futures markets, 1989), (Lein \& Tse, Physical delivery versus cash settlement:an empirical study on the feeder cattle contract, 2002), (Lein \& Tse, A survey of physical delivery versus cash settlement in futures contracts, 2006). Commodity derivative markets in India have grown by leaps and bounds over the last two decades (Ahuja, 2006), (Guru, 2009), (Masood \& Chary, 2016). Further commodity derivative markets have been the mentioned in a number of studies related to risk management in agriculture, and studies related to measures to assist distressed farmers (Planning Commission , 2006), (Reserve Bank of India, 2006), (Ahluwalia, 2019). However, these studies do not see cash settled option derivatives as a solution and prefer to suggest other measures such as insurance, income transfers etc. to overcome farmers' distress. (Karande, 2017). 
Recent studies by agricultural experts point out that procurement through the MSP mechanism in India is not a dependable mechanism (Ali, Sidhu, \& Vatta, 2012), (Niti Aayog, 2016) (Ahluwalia, 2019). Farmers in India have been facing problems in selling their produce at minimum support prices because of ineffective procurement system (Ahluwalia, 2019), delays in setting up procurement centers, lack of warehousing, and problems created by commission agents who most of the time buy produce at prices below the MSP prices (Vasudeva, 2017). In contrast to the earlier studies which suggest traditional solutions like insurance, improvements in procurement infrastructure, etc. the present paper is the first of its kind to suggest cashsettled options in MSP commodities as a solution.

Cash Settled Options: The Mechanism: One solution to overcoming the problem of lack of efficacy of the minimum support price (MSP) mechanism in many states in India, may be creation of a cash-settled commodity option market for MSP commodities with the government participating as a seller of put options. Further the government as a participant in the option market should also be committed to selling (or writing) puts at a strike price higher or equal to the minimum support price. This will ensure that a farmer who has bought a put (which is a right to sell the commodity in question), at the start of the sowing season and finally decides to exercise the option at the time of harvesting, will get a price which is at least equal to the minimum support price. If the open market price i.e., price at which the open market is willing to buy the farmer's produce, is below the put option strike price (which is the more than or equal to the minimum support price), then the farmer can exercise the option. Cash settlement implies that the amount of money the farmer will get is equal to the difference between the strike price and the open market price. The mechanism ensures that any loss to the farmer by selling the produce in the open market is covered by the money received from the option market through the cash settlement mechanism. However, if the open market price is higher than the option strike price, the farmer has the choice to allow the option contract to expire without exercising it. The loss to the farmer is the premium paid at the time of booking the contract. The government to the extent it is entering the market as a put option seller, can ensure that the premium is low.

Feasibility and Requirements: Commodity futures and options markets are not new to India. Commodity exchanges such as MCX (Multi Commodity Exchange) and NCDEX (National Commodity and Derivatives Exchange) currently trade in futures contracts in several agricultural commodities such as wheat, chana, barley, guar gum, jeera, maize, cotton, cardamom, black pepper, castor seed, crude palm oil, rubber etc. The expertise of MCX and NCDEX can harnessed to introduce cash settled commodity options in minimum support price (MSP) commodities. The following quote from the MCX website sums up the role played by the Multi Commodity Exchange: "With highly fragmented markets and volatile commodity prices, it is a challenge to ensure a 'fair' and 'remunerative' price for the Indian farmer. Keeping these in mind, the government introduced a number of reforms. In all this, the strengthening of existing institutions in spot and derivative trade has become crucial as commodity markets do influence the lives of millions of stakeholders in the country's diverse and large commodity ecosystem" (MCX India, 2019). A key requirement for effective operation of the cash settled option market in any particular commodity is a reference spot price or a reference index. The reference spot price has to be based on an existing spot price in a specific market (or location) and in relation to specified quality, delivery terms and conditions. MCX and NCDEX have expertise in this area which can be harnessed. Government entering the option market as a buyer and/or seller of option contracts is a key requirement for the effective functioning of the option markets in MSP commodities.

Advantages and Benefits of Cash Settled Options Contracts: If a commodity option market uses physical delivery mechanism for contracts which are outstanding at the time of expiry, there are many problematic issues such as quality of the commodity, place of delivery, storage and transportation charges which need to be tackled. Since the commodity option market which is being suggested in this paper is cash settled, problems of physical delivery and storage, differences in grades and quality of the commodity etc. are not issues of concern. Although there will be differences in the quality (and delivery location) of the agricultural commodity produced by the farmer and the quality (and delivery location) of the commodity quoted in the reference spot price, it can be safely assumed that prices of both the products will move in tandem. When a farmer decides to exercise the put option (which he has purchased earlier at the time of sowing) because the current reference spot price is less than his original strike price, the amount of money paid by the exchange will be difference between the original strike price and the current spot price. 
Since the original strike price is higher than the current spot price (and the farmer has agreed to sell the commodity, at the original strike price as per the put option), he will get the difference amount which would be enough to cover the losses he would incur by the selling his produce in the nearest commodity market. The government will have to pay the difference amount because it has entered the market as seller of the put option, and therefore it has an obligation to buy the commodity at the original strike price, or pay the difference under the cash settlement process. This effectively implies that the government is ensuring that the farmer gets the "minimum support price".

\section{Conclusion and Recommendations}

The Government of India has been using the minimum support price mechanism (MSP) for the last several decades to ensure that farmers get remunerative prices for their crops. However, the MSP mechanism in India is faulty and ineffective in 20 of the 22 crops covered under this policy (exceptions are wheat and rice). The resultant effect has been farmers' distress because they are forced to sell their output at prices below their cost of production during bumper crop production years. Cash settled options will ensure that farmers can effectively hedge against the possibility of un-remunerative prices for their output. Cash settled agricultural options markets may also reduce the problem of cyclicality in production of agricultural commodities. Farmer awareness (and education) to use such markets is required. Indian cooperative banks and rural bank branches which are already providing farm loans may be able to help in the process of creating farmer awareness and in educating farmers. Banks may also be able help in providing a mechanism for farmers to book option contracts, and also in the option settlement process. In conclusion, this paper strongly argues for introduction of cash-settled options in all MSP commodities in India, with the government agencies entering the market as writers (sellers) of put options. The paper further recommends that the government should write the put options at the minimum support prices fixed by the CACP (Commission for Agriculture Costs and Prices) so that farmers get the right price for their output. The recommendations of this paper are general enough to be implemented in other countries where un-remunerative crop output prices are destroying the farming industry. 


\section{References}

Ahluwalia, M. S. (2019, Jan 31). Six steps to tackle farm distress and make farming profitable.

Ahuja, N. L. (2006). Commodity derivatives market in India: Development, regulation and future prospects. International Research Journal of Finance and Economics, 2(1), 153-162.

Ali, S. Z., Sidhu, R. \& Vatta, K. (2012). Effectiveness of Minimum Support Price Policy for Paddy in India with a Case Study of Punjab. Agricultural Economcis Research Review, 231-242.

Chan, L. \& Lein, D. (2003). Using hihg, low, open, and closing prices to estimate the effects of cash settlement on futures prices. International Review of Financial Analysis, 12(1), 35-47.

Cornell, B. (1997). Cash settlement when the underlying securities are thinly traded: A case study. Journal of Futures Markets: Futures,Options, and Other Derivative Products, 17(8), 855-871.

Guru, A. (2009, January). Indian derivative markets: Some policy issues. NSE NEWS.

Karande, K. (2017, April 7). Commodity Options in India.

Lein, D. (1989). Cash settlement provisions on futures markets. Journal of Futures Markets, 9(1), 263-270.

Lein, D. \& Tse, Y. K. (2002). Physical delivery versus cash settlement:an empirical study on the feeder cattle contract. Journal of Empirical Finance, 9(4), 361-371.

Lein, D. \& Tse, Y. K. (2006). A survey of physical delivery versus cash settlement in futures contracts. International Review of Economics \& Finance, 15(1), 15-29.

Masood, S. \& Chary, T. S. (2016). Performance of commodity derivative markets in India. Amity Journal of Finance, 1(1), 131-148.

MCX India. (2019). Retrieved from https://www.mcxindia.com/

Niti Aayog. (2016). Evaluation Report on Efficacy of Minimum Support Prices (MSP) on Farmers. New Delhi: NITI AAYOG.

Planning Commission. (2006). The Working Group on Risk Management in Agriculture. New Delhi: NITI AAYOG.

Reserve Bank of India. (2006). Report of the working group to suggest measures to assist distressed farmers. Mumbai: Reserve Bank of India.

Vasudeva, V. (2017, July 22). What is the lowdown on minimum support price for crops? The Hindu, 3. 